jects... and individual staff projects. Summer, therefore, is not a slack time, but rather the most important library 'business' time of the year."

One LIBRAS library will serve as the Mentor Library with a number of cooperating libraries serving as field trip sites to provide a depth of exposure and experience not possible if the entire program were confined to one institution. LIBRAS will extend a $\$ 1,000$ stipend and a $\$ 200$ room allowance. The intern is responsible for transportation and incidental expenses. Applicants must have completed one year of library school or be currently employed in a college library. The intern will complete a written report of the experience which will include, but not be limited to, such activities as a supervised reading program in library management, shadowing the host director, analyzing the library budgeting process, comparing the library's organization chart and job descriptions with the realities of day-to-day activities, and helping revamp collection development policy and mission statements.

Internship applicants should submit a letter and resume by March 1, 1987, to: Jonathan D. Lauer, Chair, LIBRAS Internship Committee, Aurora University, Aurora, IL 60506.

\title{
ACRL actions, July 1986
}

\section{Highlights of the Annual Conference meetings of the ACRL Board of Directors.}

$\mathbf{T}_{\mathrm{h}}$ Lef lege and Research Libraries met twice during the ALA Annual Conference in New York: on June 28, 1986, and July 1, 1986.

\section{American Council on Education}

The Board endorsed the statement of the American Council on Higher Education, "A Call to Conscience," in support of funding for higher education at the Federal level.

\section{BIS Think Tank}

The Board endorsed in principle the concept of a Bibliographic Instruction Section Think Tank retreat in June 1987, contingent upon the section's success in raising funds for it.

\section{Budget}

The Board approved the ACRL budget for 1986-87, which projects a deficit of approximately $\$ 50,000$, largely for the work on Books for College
Libraries, 3d edition.

\section{Chapters}

The Board approved the petition for the establishment of an ACRL chapter in Alabama.

\section{Cinema Librarians}

The Board dissolved the Cinema Librarians Discussion Group. The Art Section has expanded its program coverage of the visual and performing arts and will be increasingly concerned with topics of interest to cinema librarians.

\section{Commemorations}

The Board voted to observe the 100th anniversary of the founding of the ALA College Library Section-the forerunner of ACRL-at the ACRL Fifth National Conference in Cincinnati in 1989, and the 50th anniversary of the establishment of the Association of College and Reference Libraries (as ACRL used to be called) at the ALA Annual Conference in Chicago in 1990. 


\section{Committees}

The Board approved a charge for the new Academic Library Statistics Committee and a revised charge for the Professional Education Committee.

The Board also encouraged Board members to voluntarily visit certain committees as part of their Board assignment. Members can choose any ACRL standing committee, any section executive committee, Chapters Council, or Activity Sections Council.

\section{Conference meetings}

The Board voted to require that section chairs be required to coordinate section meetings at ALA Annual Conferences and Midwinter Meetings; that sections, standing committees, and discussion groups take action to reduce the number of programs and meetings at ALA conferences; and that they investigate more creative use of time blocks.

The Board approved eleven program plans for the San Francisco Annual Conference, June 27-July 2, 1987. The May 1987 C $\triangleleft R L$ News will carry full program details.

\section{Division Leadership Enhancement}

The Board moved to support the Division Leadership Enhancement Program.

\section{Elections}

The Board approved a proposal for the production of a videotape in which the two candidates for ACRL Vice-President/President-Elect would be introduced, share their views on ACRL, and have some interaction with the audience. The videotape will be produced at the 1987 Midwinter Meeting in Chicago at a local college. Copies will be made for distribution to ACRL chapters or other groups with a legitimate interest in ACRL elections.

\section{Fifth ACRL National Conference}

The Board accepted the suggestions of the Executive Committee on the organization of the Fifth ACRL National Conference in Cincinnati in 1989: that the chair of the Conference Planning Committee be a past ACRL President or other Board member who is committed to ACRL National Conferences; that theme and program suggestions come from the national level; that an advisory committee of past conference committee members be formed; and that ACRL chapters in the Cincinnati area be contacted to learn of their interest in working on the conference. ACRL President Hannelore Rader will appoint the National Conference Committee by the Midwinter Meeting 1987.

\section{Grants}

The Board voted to require that every grant going forward with ACRL approval be reviewed for content and competence, and that the Board ap- prove and (where appropriate) send forward only one proposal to each granting agency or, failing that, a ranked set of proposals.

\section{Legislation}

The Board approved the continuation of the Legislation Committee following review by the Planning Committee; and requested that the Committee make a formal proposal on how additional funds from ACRL could be used to increase ACRL involvement in ALA's Legislative Day. The Planning Committee will review the composition of the Legislation Committee.

\section{Membership}

The Board approved the continuation of the Membership Committee following review by the Planning Committee; directed the ACRL Executive Director to assign the same staff member as ACRL Office Liaison for both the Membership Committee and Chapters Council; asked the Committee to explore alternative structures for committee membership and send a proposal with a rationale to the Planning Committee; and asked that the Committee talk with ACRL staff about the advisability of exploring strategies for increasing the number of organizational members.

\section{Millicent Abell}

The Board honored Millicent (Penny) Abell for her 10 years of service as a member of the ACRL Board of Directors. She was presented with a framed certificate after the meeting.

\section{Performance measures}

The Board directed the ACRL staff to work with the chair of the Ad Hoc Committee on Performance Measures to prepare an RFP for the production of a manual of academic library performance measures and to bring the RFP to the Board before the 1987 Midwinter Meeting.

\section{Rare Books \& Manuscripts Librarianship}

The Board extended the evaluation period for Rare Books \& Manuscripts Librarianship through its third issue to be published in the Spring of 1987.

\section{RBMS bylaws}

The Board approved the proposed revision to the Rare Books and Manuscripts Section bylaws, as reported in C\&RL News, September 1986, p.502.

\section{Standards and Accreditation}

The Board rescinded all documents based on the 1975 Standards for College Libraries. (The 1986 Standards, approved by the Board at the Midwinter Meeting, were published in the March 1986 issue of $C \& R L$ News.) The outdated documents, College Library Standards: Questions and An- 


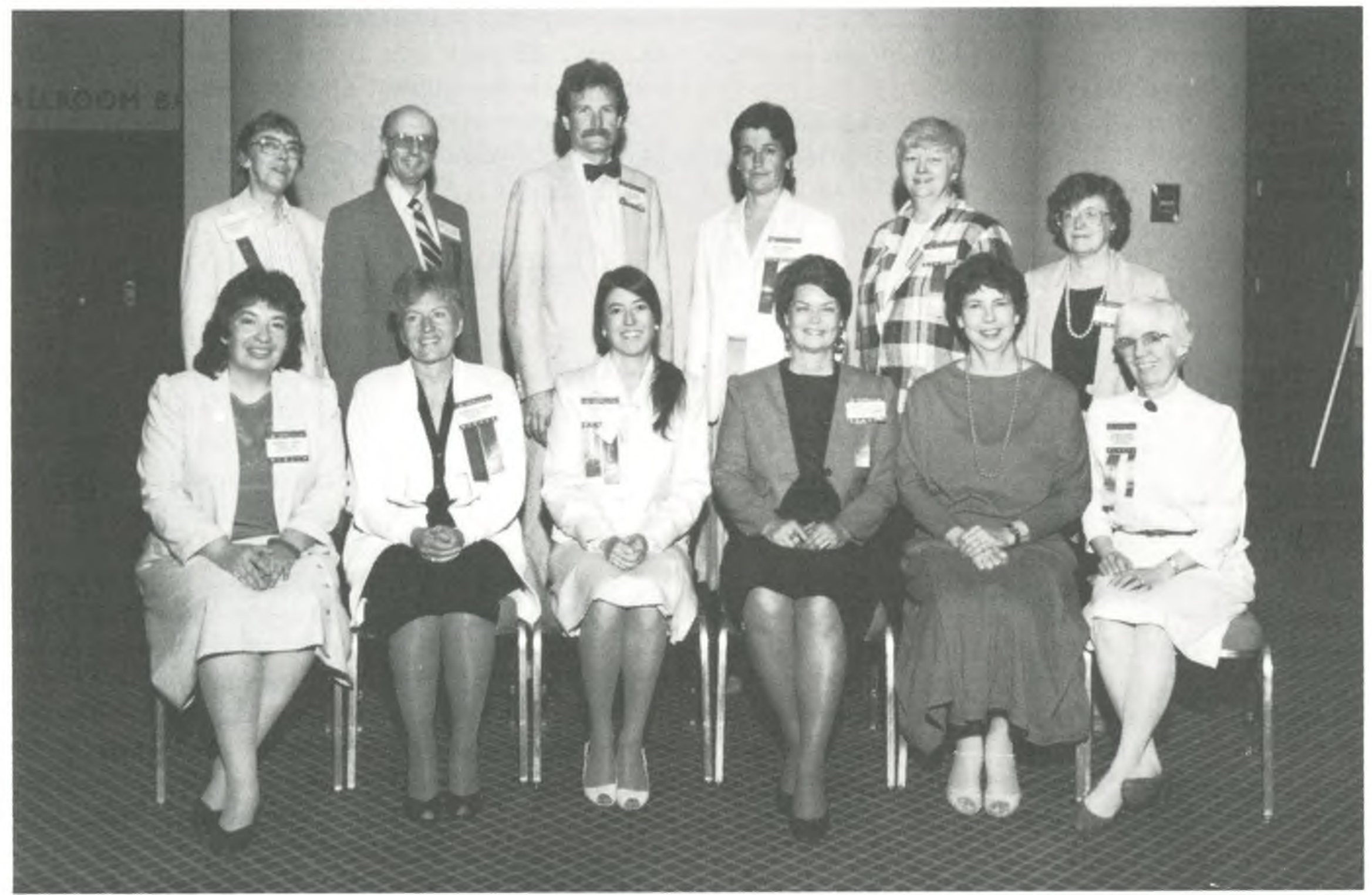

ACRL Board of Directors, 1985-86. Back row: Alexandra Mason, Robert Almony, W. Lee Hisle, Mary Sue Ferrell, Jean Major, B. Anne Commerton. Front row: Rochelle Sager, Hannelore B. Rader, Sharon A. Hogan, Sharon J. Rogers, Millicent Abell, JoAn Segal. Not present: Edward J. Jennerich, Bob D. Carmack.

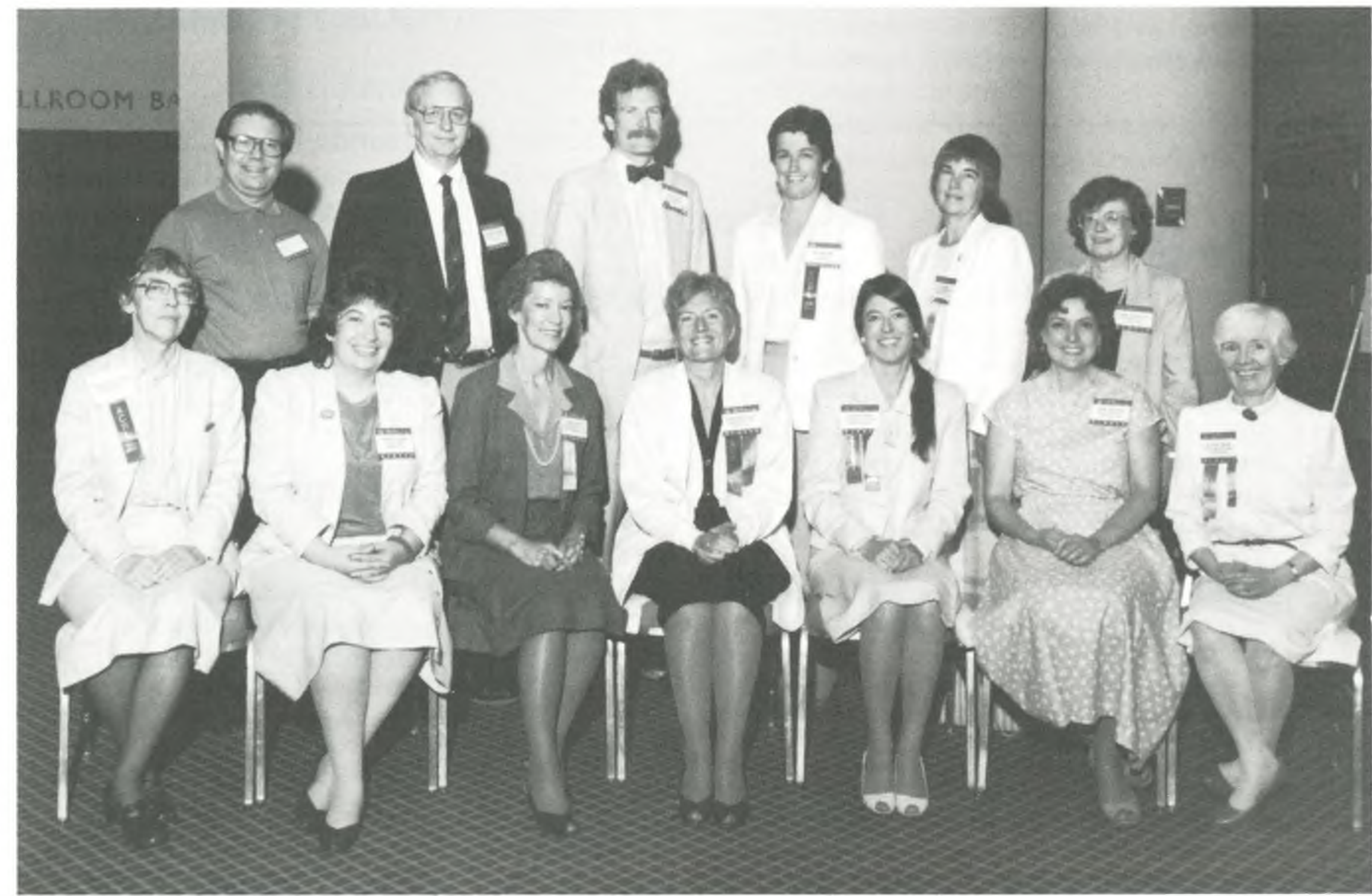

ACRL Board of Directors, 1986-87. Back row: Thomas Kirk, Melvin R. George, W. Lee Hisle, Mary Sue Ferrell, Elizabeth M. Salzer, B. Anne Commerton. Front row: Alexandra Mason, Rochelle Sager, Joanne R. Euster, Hannelore B. Rader, Sharon A. Hogan, Anne K. Beaubien, JoAn Segal. Not present: Edward J. Jennerich, Bob D. Carmack, Patricia A. Wand. 
swers and An Evaluative Checklist for Reviewing $a$ College Library Program, will no longer be available from the ACRL Office.

The Board made the following change in the charge of the Standards and Accreditation Committee: "Holds or delegates the holding of open hearings on ACRL standards before they are recommended to the Board" (italicized wording is new).

The Board also approved a proposal that the Standards and Accreditation Committee serve as the editorial advisory committee for an ACRL manual on accreditation processes. The publication will also be reviewed by the ACRL Publication's Committee's Subcommittee on Non-Serial Proposals.

\section{Statistics}

The Board directed that ACRL staff collect data from non-ARL university libraries, as well as those college and community college libraries covered by the 1984 ACRL 100 statistics survey, using a modified Department of Education questionnaire, and that results be disseminated in a format comparable with previous years.

\section{Strategic Plan}

The Board adopted in principle the Strategic Plan presented by the ACRL Strategic Planning Task Force; voted to adopt the strategies identified for implementation in 1986-87 and to fund them from reserves; and adopted the proposed process for the development of an annual operating plan, specifying that it be implemented in planning for the 1987-88 year. The Board discharged the Task Force with the highest appreciation. The Executive Director coordinated the 1987-88 Strategic Plan objectives and strategies with those of ALA during the ALA Annual Planning retreat in August 1986.

\section{Task forces}

The Board approved the establishment of four new ACRL task forces:

-The Task Force on Libraries and Computer Centers will investigate cooperative ventures between academic libraries and computing facilities and will draft guidelines for such cooperation.

- The Task Force on Library Access will respond to the Lacy Report in terms of bibliographic and public access to academic library facilities and materials; they will develop guidelines for academic libraries to formulate access policies.

- The Task Force on Librarians as Instructors will investigate the role of academic librarians as instructors both in subject disciplines and in library schools and will recommend guidelines for librarians, supervisors, and the instructional unit.

- The Task Force on Fundraising will study fundraising activities within academic libraries and provide advice to academic librarians interested in development work.

The Board also received the final report of the Task Force on Support of New Committee Members and Chairs and discharged the Task Force with thanks.

\section{CD for authoritative, complete, comparative reviews of current books of lasting value.}

CHOICE reviews more serious books than any other reviewing medium in the United States. Its reviews, written by college faculty throughout the U.S. and Canada, are succinct and balanced, placing each book within the literature of its field and indicating its appropriate readership level. Included are publications from American and Canadian firms, as well as many titles published abroad but distributed through North American representatives. Bibliographical information is entered, in standard library format for easy reference.

Published by the Association of College and Research Libraries, CHOICE has long been recognized by the college world as an essential book selection tool. Its circulation of approximately 6,000 reaches virtually every university and community college in North America and many of the leading academic institutions and libraries of Europe, Asia, and the Far East.

Please enter our subscription to CHOICE for one year at $\$ 110.00$.

$\square$ Foreign subscription: $\$ 120.00$ (in U.S. dollars, drawn on U.S. bank).

\section{CHOICE}

Subscription Department

100 Riverview Center

Middletown, Connecticut 06457

Tel. (203) 347-6933

\section{Name}

Address 